\title{
La innovación y la tecnología como recursos en el proceso de internacionalización de empresas colombianas ${ }^{12}$
}

\author{
Innovation and technology as resources in the internationalization \\ process of colombian companies \\ A innovação e a tecnologia como recursos no processo \\ de internacionalização de empresas colombianas
}

\author{
Alexandra Donado Mercado \\ Facultad de Ciencias Económicas \\ y Empresariales, Universidad Santiago \\ de Cali, Colombia. \\ E-mail: alexandra.donado00@usc.edu.co \\ Viridiana Núñez López \\ Departamento de Administración, \\ IDITPYME, Centro Universitario de \\ Ciencias Económico Administrativas, \\ Universidad de Guadalajara. Zapopan \\ Jalisco, México. \\ E-mail: viridiananunez@hotmail.com
}

\author{
Ricardo Arechavala Vargas \\ Departamento de Administración, \\ IDITPYME, Centro Universitario de \\ Ciencias Económico Administrativas, \\ Universidad de Guadalajara. \\ Zapopan Jalisco, México. \\ E-mail: arechavala@stanfordalumni.org
}

Fecha de recepción: 30/10/2017 Fecha de aceptación: 28/12/2017

Palabras clave

- Exportaciones

- Innovación

- Tecnología

\section{Resumen}

El objetivo de esta investigación es probar la incidencia de ciertas variables en el desempeño exportador de empresas MIPYMES asentadas en Colombia. A diferencia de la mayoría de los estudios empíricos, enfocados a nivel país o industria, esta investigación es a nivel de empresa. Utilizando análisis estadístico se prueba la incidencia de las variables: innovación, intensividad de conocimiento, así como características del emprendedor y de la empresa (edad del emprendedor, escolaridad del emprendedor y tamaño de la empresa) en un total de 241 empresas de todos los sectores, ubicadas en Cali. Los principales hallazgos son que las variables: inno-

(1) Los autores agradecen a la Unidad de emprendimiento e innovación empresarial de la Cámara de Comercio de Cali, Colombia por facilitar el acceso y uso de la base de datos del programa Valle Impacta 2015 y Alianzas 2016.

(2) Artículo presentado en el III Congreso internacional ICSB México. 
vación, intensividad de conocimiento y escolaridad del emprendedor están correlacionados positivamente con el desempeño exportador. Los resultados obtenidos en la presente investigación pueden servir de guía al momento de tomar decisiones sobre a qué tipo de empresas apoyar en su proceso de internacionalización.

\begin{abstract}
The aim of this research is to demonstrate the impact of some variables on the exporting performance of MSMEs settled in Colombia. This research is carried out with a focus on the company, which differs from most of the empirical studies -focused on the country or industry. With the use of statistical analysis, the impact of the following variables is proven: innovation, knowledge intensity, entrepreneur and company's characteristics (entrepreneur's age and academic background and size of company). The analysis includes 241 companies from all economic sectors, located in Cali. According to the main findings, there is a positive correlation between the variables innovation, knowledge intensity and entrepreneur's academic background and the company's exporting performance. The outcomes of this research may provide useful guidelines to decide on which kind of companies should be supported in their internationalization process.
\end{abstract}

Keywords - Exports

- Innovation

- Technology

\section{Palavras-chave}

- Exportações

- Inovação

- Tecnologia

\title{
Resumo
}

0 objetivo desta pesquisa é provar a incidência de certas variáveis no desempenho exportador de empresas MIPYMES assentadas na Colômbia. À diferença da maioria dos estudos empíricos, focados a nível país ou indústria, esta pesquisa é a nível de empresa. Utilizando análise estatística prova-se a incidência das variáveis: inovação, intensidade de conhecimento, assim como características do empreendedor e da empresa (idade do empreendedor, escolaridade do empreendedor e tamanho da empresa) em um total de 241 empresas de todos os setores, situadas em Cali. Os principais achados são que as variáveis inovação, intensidade de conhecimento e escolaridade do empreendedor estão correlacionados positivamente com o desempenho exportador. Os resultados obtidos na presente pesquisa podem servir de guia no momento de tomar decisões sobre que tipo de empresas apoiar em seu processo de internacionalização. 